GEORGETOWN SCIENTIFIC RESEARCH JOURNAL
Volume One Edition One

February 2021

\title{
The Preventative and Healing Properties of Performing Arts in Female Genital Mutilation
}

Alyssa Kardos 


\title{
The Preventative and Healing Properties of Performing Arts in Female Genital Mutilation
}

\author{
Alyssa Kardos \\ Department of International Health, Georgetown University, Washington, \\ D.C., United States
}

E-mail: aek106@georgetown.edu

\begin{abstract}
Despite being outlawed in many of the countries where it is the most prevalent, female genital mutilation (FGM) still persists. It is critical that innovative interventions be adopted in order to better address the cultural roots of this gender violence epidemic. The aim of this study is to explore the use of performing arts to fill this gap in effective preventative and treatment interventions. Due to the lack of data in this field, this study comprises of an extensive literature review. Existing programs were evaluated through thorough web searches, interviews of program leads, and analyses of the results. After reviewing existing evidence, it has been concluded that performing arts interventions provide positive outcomes in the field of FGM due to their ability to engage with cultural assumptions, incite empathy, and cross educational boundaries, all through community-connected approaches. Local outcomes were connected to government intervention in the recommendations to conclude that all governments should ban FGM, allocate public funds to the field of arts and health, and increase the validity of performance-based interventions through increased and improved research.
\end{abstract}

Keywords: Female Genital Mutilation (FGM), Performing Arts, Performance, Theatre for

Development

\section{Introduction}

In the fight to end FGM, outlawing the practice has proved to not be enough. For example, in Egypt, FGM has been a crime since 2008 , but the number of women between the ages of 15 and 49 who have undergone FGM is still as high as $91 \%$ in $2020^{1,2}$. In order to work towards the abandonment of FGM, interventions must target attitudes and behaviors at the individual and community levels. By honing in on the root causes of FGM, these targeted interventions can initiate open and honest discussions about the negative impacts of FGM in order to contribute to meaningful change ${ }^{3}$.

FGM, while a tradition in many cultures, is a violation of human rights. By directly engaging the complex driving forces behind this phenomenon, performative art has been promising in the process of changing the behavior and beliefs of those abetting the practice of FGM, including mothers, religious leaders, and circumcisers. While there is a very limited amount of research on the quantitative effectiveness of using performing arts to reduce the practice of FGM, the existing accounts are hopeful for the future of this nexus. 
This study serves to gather existing accounts and research to propose performance as an underutilized but nonetheless helpful intervention for the prevention and treatment of FGM, because of its abilities to cross language barriers, engage empathy, empower self-expression, and challenge culturally ingrained issues.

The field of performative arts (including theater, dance, music, and radio) and its role in health interventions is becoming more relevant in research. Just over the past two decades, academia, NGOs, and many governments have increasingly conducted research on the effects of the arts overall on health and well-being ${ }^{4}$. The Health Evidence Network Synthesis Report 67, which focused on the evidence of the arts in improving health and wellbeing, synthesized evidence from over 900 publications at the intersection of arts and health and gives recognition to the positive role of arts on health. The results are clustered into two themes: prevention and promotion, and management and treatment. Under prevention and promotion, the report found that the arts can affect the social determinants of health, support child development, encourage health-promoting behaviors, help to prevent ill health, and support caregiving ${ }^{4}$. In the theme of management and treatment, the findings displayed that the arts could help people experiencing mental illness, support care for people with acute conditions, help to support people with neurodevelopmental and neurological disorders, assist with the management of non-communicable diseases, and support endof-life care ${ }^{4}$. This report serves as proof of the tangible and impactful effect the arts can have on individual well-being and global health.

FGM is one health issue in which the arts can benefit survivors and those at risk by facilitating healing and targeting incidence. While Finn and Fancourt's Health Evidence Network Synthesis Report does not cover FGM in its evidence, arts interventions were successful in improving other culturally embedded global health issues, such as the stigma against LGBTQ communities. As FGM also requires culturally sensitive solutions, the arts have the potential to be transformative in this health issue's outcomes.

The topic of FGM is especially pertinent in 2020 as a result of COVID-19 lockdowns. There are severe long- and short-term implications of these policies. In the long term, estimates provided by Avenir Health, Johns Hopkins University, and Victoria University predict that lockdown-related disruption over six months will disrupt programs to end FGM, potentially resulting in two million additional cases of FGM over the next 10 years ${ }^{5}$. The Kapenguria Theater Group, a theater group fighting FGM, reported in July 2020 that the number of girls being circumcised has drastically risen since schools were closed due to COVID$19^{6}$. Given these increased rates of FGM and the subsequent need to find unique interventions, it is critical to produce effective and innovative projects combatting FGM.

Sections 3 and 4 will introduce the topics of FGM and performance for development. Section 5 will assess existing performance programs working in FGM prevention and health promotion through covering existing research and giving an overview of existing programs through an in-depth internet search and interviews with professionals working at the programs. Section 6 will look at the ways in which performance is used to improve mental health outcomes of survivors of FGM.

Due to a lack of reporting of data and awareness of positive evidence of the arts in health interventions, there has been little translation from projects to policy ${ }^{4}$. Section 7 will report on current policy revolving around FGM and arts interventions and give recommendations on moving towards the solution.

\section{Methodology}

In order to achieve the aim of this research, the chosen methodology integrated literature review, expert background knowledge, quantitative data in health databases, and primary source surveys and interviews with organizations who work in the intersection of FGM and performing arts. 
Primarily, the aim was to establish a cause-andeffect relationship between performance and FGM, stipulating that the implementation of performance interventions prevents FGM and improves outcomes for survivors. In order to do so, both quantitative and qualitative data were required. The literature review allowed for synthesis of already existing research, though limited, to include a blend of quantitative and qualitative data. It was especially important that journals from countries where FGM is the most prevalent were included. Other sources outside of journals could include newspaper articles, in particular theater reviews, and books on the subject of FGM or performing arts in development and health.

Background research that was conducted also included speaking with experts in the broader area of arts and health. The interviews incorporated both short surveys to collect basic information and longer interviews encompassing a comprehensive review of the organization's work. Criteria for interview was kept to representatives of organizations with performance-based FGM interventions. Due to the limited number of research and practice in this specific area, no other factors for interview criteria were restricted. Interviewees were based in several different countries, including Egypt and Italy. As seen in Table 1, each interviewee answered a list of questions over a Zoom interview. The interviews were later transcribed in order to search for keywords and themes across programs and descriptions.

\section{Table 1. FGM Organization Interview Guide}

\begin{tabular}{|l|l|}
\hline Main Question & $\begin{array}{l}\text { Probes and Further } \\
\text { Question }\end{array}$ \\
\hline $\begin{array}{l}\text { 1.What kind of } \\
\text { programming does } \\
\text { your organization } \\
\text { do at the } \\
\text { intersection of }\end{array}$ & $\begin{array}{l}\text {-Please describe the programs } \\
\text { in more detail. } \\
\text {-Where do you work? } \\
\text {-Approximately how many } \\
\text { people have you served/how }\end{array}$ \\
\hline
\end{tabular}

\begin{tabular}{|l|l|}
\hline $\begin{array}{l}\text { performance and } \\
\text { FGM? }\end{array}$ & $\begin{array}{l}\text { many people does each project } \\
\text { reach? }\end{array}$ \\
\hline $\begin{array}{l}\text { 2. Do you utilize a } \\
\text { specific } \\
\text { methodology in } \\
\text { your organization? }\end{array}$ & $\begin{array}{l}\text {-What does community } \\
\text { participation look like during } \\
\text { the programs? } \\
\text {-Which populations do you try } \\
\text { to reach? } \\
\text {-Where did this methodology } \\
\text { come from? }\end{array}$ \\
\hline $\begin{array}{l}\text { 3.What are your } \\
\text { measures of } \\
\text { success? }\end{array}$ & $\begin{array}{l}\text {-Does your organization have } \\
\text { public reports of project } \\
\text { evaluations? } \\
\text { - What are the results of the } \\
\text { programs in these } \\
\text { measurements? }\end{array}$ \\
\hline $\begin{array}{l}\text { 4.Have you seen } \\
\text { any translation of } \\
\text { work in performing } \\
\text { arts and FGM into } \\
\text { legislation? Is so, } \\
\text { where? }\end{array}$ & \\
\hline $\begin{array}{l}\text { 5.Where do you see } \\
\text { the future of your } \\
\text { programs going? } \\
\begin{array}{l}\text { Where do you see } \\
\text { the future of this } \\
\text { intersection going? }\end{array}\end{array}$ \\
\hline $\begin{array}{l}\text { 6.Do you have any } \\
\text { helpful article, } \\
\text { book, or video } \\
\text { recommendations } \\
\text { for further } \\
\text { research? }\end{array}$
\end{tabular}

\subsection{Health Promotion Models and Theories}

The analyzed and proposed interventions in this paper fall under the broad category of global health promotion, as they seek to enable people to "increase control over, and to improve their health" ${ }^{\prime}$. As such, it is important to consider health promotion theory and models in the application of performance as a tool to prevent FGM. The social- 
ecological model traditionally reflects the range of factors that put people at risk of violence. In Figure 1 , this model was applied to reflect the different groups influencing the practice of FGM, centered on the individual as the female at risk of FGM, in order to understand the range of audiences for consideration in approach. Each group, with its own motivations and backgrounds, may require different approaches in order to shift beliefs and attitudes toward FGM.

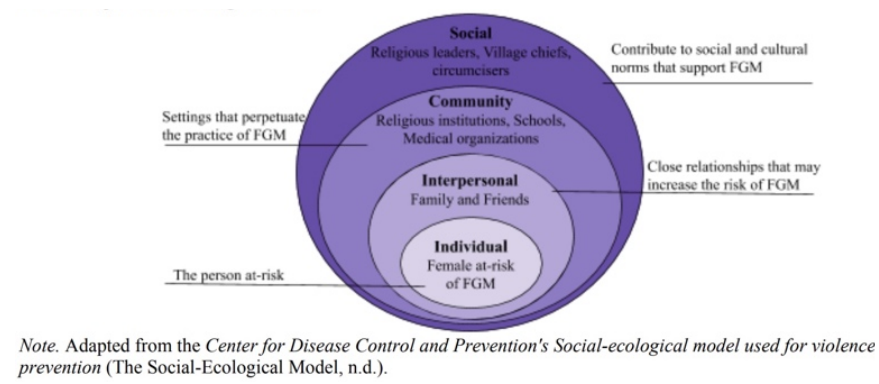

Figure 1. FGM Groups Social-Ecological Model

\subsubsection{Individual and Interpersonal.}

The theory of planned behavior (TPB) serves as a useful framework to evaluate the potential impact of interventions on the individual and the effects of interpersonal relationships. The focus of this model is behavioral intent, which predicts actual behavior. The theory states that behavioral intentions are influenced by the attitude towards a behavior, subjective norms, the perceived societal approval rating of the action, perceived behavioral control, and the individual perception of one's own agency ${ }^{8}$. The TPB has successfully been used to predict other behaviors and intentions including smoking, drinking, and health service utilization.

\subsubsection{Community and Social.}

Social network theory benefits the understanding of an individual's larger networks. This theory posits that social networks can positively or negatively influence an individual's health behaviors or outcomes. The network's effects are attributed to the types of connections an individual has, based on technical measures such as density, size, centrality, homogeneity, and frequency of ties. Types of interventions include enhancing existing networks through the development of new social linkages, creation of community health workers, and advancing community capacity building.

\subsection{Measures of Success}

FGM is very difficult to monitor, because it is unethical to check for its occurrence (invasion of privacy). Instead, data is reliant on self-reporting, which in turn, raises issues in the data collection. Data is underreported due to many factors, including a lack of criminal procedure in both developed and developing countries, the controversial practice of having children who have undergone FGM speak against their parents in court, and a lack of infrastructure for monitoring capabilities ${ }^{9}$. Furthermore, self-reporting has been recognized as very unreliable ${ }^{10}$. As such, organizations more frequently measure the success of interventions through qualitative means, including testimonials, increased rates of female education, and overall spending on healthcare. As performance-based interventions are variously implemented and rarely evaluated by the same means, it is necessary to interpret results as indicators, in lieu of definitive results.

This study will focus on these indirect measures in order to evaluate the success of interventions.

\section{Background on Female Genital Mutilation}

The World Health Organization (WHO) classifies FGM as "all procedures that involve partial or total removal of the external female genitalia, or other injury to the female genital organs for non-medical reasons" ${ }^{11}$. The practice is primarily carried out on young girls between infancy and age $15^{11}$. WHO is firm in stating that FGM has no health benefits and only harms girls and women. The United Nations Population Fund-United Nations Children's Fund (UNFPAUNICEF) Joint Programme on FGM estimates 
that more than 200 million women and girls worldwide have been deliberately mutilated, specifically in 30 countries $^{12}$.

Out of the 30 countries listed, the rates of FGM differ per location. In countries such as Somalia, Guinea, Djibouti, Egypt, and Mali over $90 \%$ of women and girls aged 15-49 have undergone some form of $\mathrm{FGM}^{12}$. Table 2 (in the appendix) shows the aforementioned and other relevant countries with high prevalence rates. Meanwhile, other countries qualify as practicing FGM primarily due to the presence of diaspora communities ${ }^{13}$. Approximately 180,000 girls and women within large African diaspora communities in Europe are at risk each year ${ }^{14}$.

However, as reported by The Guardian in early 2020, the number of FGM survivors could be much higher due to the failure of countries to record cases ${ }^{15}$. While the UNFPA-UNICEF report primarily records data from 30 countries, research from Equality Now, the End FGM European Network, and the US End FGM/C Network reports "hundreds of thousands" of cases across 92 countries in Asia, the Middle East, Europe, North America, and Latin America ${ }^{15}$. The lack of data reduces the urgency of public officials to act, resulting in harmful inaction from governments. In the United States alone, over 500,000 women and girls are survivors of FGM or at risk of being victim ${ }^{15}$. Beyond the European Union and UK, cases have also been found in Iran, Israel, and Russia. Even these numbers could be underestimated, as the data largely focuses on diaspora communities and ignores other prevalent ones, such as Christian communities in the United States $^{15}$. The exact number of girls and women who have undergone FGM is still mostly unknown.

\subsection{Types of FGM}

The health risks and other adverse effects of FGM vary based on the type of FGM conducted $^{11}$.

1. Type I describes the partial or total removal of the clitoral glans and/or the clitoral hood.
2. Type II describes the partial or total removal of the clitoral glans and the labia minora, sometimes with the removal of the labia majora.

3. Type III is also known as infibulation, which is the narrowing of the vaginal opening by sealing it. The seal is created through repositioning and stitching.

4. Type IV includes other non-medical, harmful procedures to female genitalia, including nicking, piercing, incising, and more.

Estimates from 2004 predict that around 90\% of FGM cases include Type I, II, or IV, and about $10 \%$ include Type $\mathrm{III}^{16}$. The present study is not concerned with the eradication of a particular type of FGM, but rather the entire practice, as all types are a violation of human rights and cause harm to females.

\subsection{Types of FGM}

The risks of FGM vary from physical to psychological to economic, with lasting negative effects. While the type of FGM, described above, determines all associated risks, overall health risks include severe pain, hemorrhage, genital tissue swelling, fever, infections, urinary problems, wound healing problems, injury to surrounding genital tissue, shock, and death ${ }^{17}$. Beyond these risks, long-term complications may include urinary problems, vaginal problems, scarred tissues, menstrual problems, and increased risk of childbirth complications, including newborn deaths, and psychological trauma.

Girls are expected to undergo FGM in order to avoid stigma and isolation from family ${ }^{18}$. Because of this, refusal to be cut can also lead to harmful socioeconomic effects. Overall, however, preventing FGM provides major benefits for women, communities and economies. The health outcomes of performing FGM results in high healthcare costs for the individual and the state ${ }^{19}$. Dr. Ian Askew, Director of WHO's Department of Sexual and Reproductive Health and Research, claims that FGM is extremely harmful to a 
country's economic resources. WHO reports that "the total costs of treating the health impacts of FGM would amount to $\$ 1.4$ billion USD globally per year, if all resulting medical needs were addressed.” FGM presents a significant economic burden for both the individual and the state.

\subsection{Reasons for Performing FGM}

\subsubsection{Individual and Interpersonal.}

There are many overlapping factors that contribute to the ongoing practice of FGM. People often tend to suspect that FGM is attributed to religion. Nevertheless, there is no evidence that supports this stereotype. In Egypt, it is a "centuries-old tradition," or "tribal ritual" embedded in the culture. Though there are no writings in religious texts that prescribe the practice of FGM, practitioners often believe that the practice has religious support ${ }^{11}$. Furthermore, in some locations, FGM is still more prevalent in certain religious communities. For example, in Burkina Faso, FGM is higher among Burkinabe Muslims than in other religious communities ${ }^{20}$. While stereotypes can conflate Islam and FGM, it is practiced by all major religions ${ }^{21}$. Furthermore, the practice of FGM predates the establishment of all major religions. Thus, while some religious communities may have higher rates of FGM, religion is not the origin or driving force for FGM.

The views of religious leaders vary: some promote it, others consider it irrelevant, and some actively contribute to its abandonment. Religious leaders and beliefs are featured in many drama skits and other advocacy efforts in order to target religious misconceptions and change attitudes. NCA Ethiopia has worked with faith leaders for over a decade, releasing joint statements condemning FGM, driving community conversations, and leading trainings. In a partnership with the Inter Religious Council of Ethiopia (IRCE), the umbrella organization for seven faith-based organizations in Ethiopia, Norwegian Church Aid released this joint statement in 2011:

"We religious fathers and leaders will seriously teach that female genital mutilation, early marriage, abduction and related harmful practices committed against women have severe consequences on the lives of our daughters, sisters, and mothers have no support in any religious teaching. We have reached an agreement for religious admonition to be administered on all people committing the practices in violation of the Call" 22 .

This statement summarizes the efforts of antiFGM organizations to collaborate with religious leaders. Performance-based interventions featuring religious leaders can be especially effective in targeting a common community misconception/assumption about FGM.

\subsubsection{Fear and Taboo.}

Ostensibly, reasons for its practice vary across region. In Ijurin, Nigeria, primary beliefs behind its practice include it being taboo not to be circumcised, an association of the clitoris and a woman being too sexually active is cultivated, the need to preserve a family's honor, a concept that the procedure widens the vagina to make birth easier, and lastly the idea that an uncircumcised woman is a sex slave ${ }^{23}$. Other factors involve the marriageability of women, a vague religious association - although, as mentioned previously, no religious text explicitly endorses the practice - local structures of power, and traditions of neighboring groups ${ }^{11}$. The practice is typically conducted by older women in the community who are traditional circumcisers ${ }^{11}$. More recently, the practice has evolved to include health care providers and medical professionals carrying out FGM, because of a belief that it could be safer than having it done by local circumcisers. Because this issue is largely cultural, interventions must be sensitive and empathetic in their approach.

The underlying causes for the perpetuation of FGM are reflected in Figure 2 through the socioecological model. This model emphasizes that no 
single factor can explain why FGM still exists or why some females face a higher risk of undergoing $\mathrm{FGM}^{24}$. Considered in this way, potential interventions can be specialized to target the varying social dynamics of each group. Strategies addressing a larger cultural norm on the societal level should look different from working with medical professionals to inform them of the harmful implications that come from medicalized FGM. This figure can be a guide to the different approaches an organization should take in order to be attentive to each level of organization.

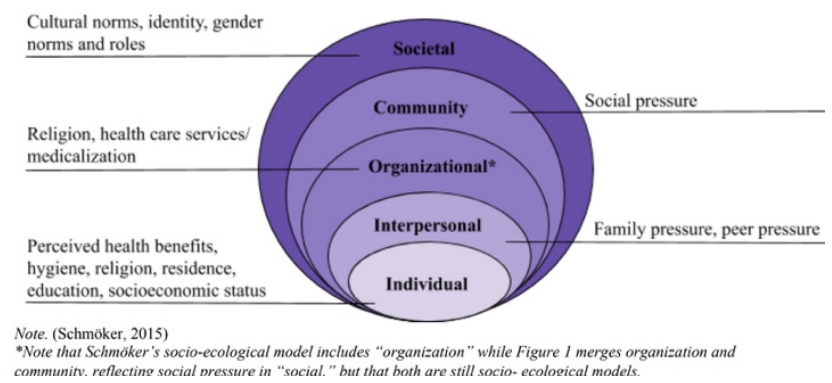

Figure 2. Socio-ecological model of the underlying factors of FGM

On the individual level, ideas involving a person's perceived health, religion, residence, and socioeconomic status are all important for understanding the reasons for undergoing FGM. All of these factors control information and knowledge a person can access at an individual level. The interpersonal level reflects the communication of an individual's beliefs, which contributes to family or peer pressure. The organizational level reinforces the existing beliefs through medicalization and religion, validating the practice through the institutions' credibility. The community and society levels reflect the desire of an individual and family to "maintain ethnic identity and social unity" by carrying out what is recognized as a tradition in their community ${ }^{24}$.

Other factors, such as gender, cross socioecological divides in their impact. The gender of the individual and genders of those in interpersonal interactions influence attitudes towards FGM. According to data compiled in
Table 3 (in the appendix), women and men have separate attitudes towards FGM, with differing opinions on whether FGM should end. Additionally, the sexuality and gender of partners greatly influences the practice of FGM. In two studies it was found that men preferred women who were circumcised based on the belief that the men would have enhanced sexual enjoyment ${ }^{24}$. With the consideration of marriage, in a study in Somalia, $96 \%$ of men preferred to marry circumcised women, while just $2.8 \%$ said they would possibly consider marrying uncircumcised women.

The methodology in Section 2 explained the intervention models which match each group. In general, the reasons for carrying out FGM are largely based in tradition that originates from misconception. In this context, performance serves as an educational platform in addition to a method of addressing deeply ingrained cultural beliefs. The explanation of its function and evidence for its effectiveness are covered in Section 5.

\subsection{Progress}

The progress toward achieving fewer instances of FGM and shifting attitudes can be measured in a few ways: the number of girls and women who want FGM to stop, the number of men who want FGM to stop, the number of women ages 15-49 who have been cut vs other age groups, and the overall number of women who have been cut (per country or otherwise). It is difficult to gather country data on each national decline because of poor data collection. Neither the World Bank nor UNICEF have consistent data for countries over the past 2-40 years ${ }^{25,26}$. Still, UNICEF was able to conclude that among girls and women in highprevalence countries, within the last two decades, the proportion of girls and women who want the practice to end has increased by $100 \%$, as displayed in Figure $3^{25}$. 


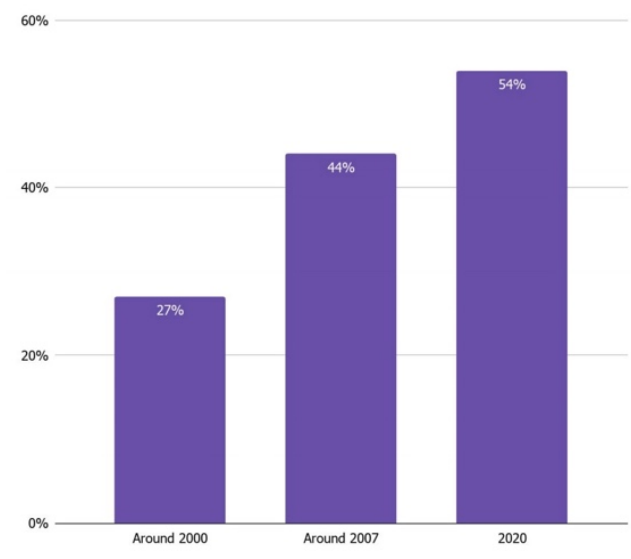

*Data gathered in 2020

Source: Female Genital Mutilation (UNICEF, 2020)

Figure 3. Percentage of girls and women aged 15 to 49 years familiar with FGM and believe that the practice should stop, in high-prevalence countries*.

At the same time, it is important to note that although the trend is still positive, the progress has slowed. Between 2000 and 2007, there was a 16\% increase in reported cases followed by a $10 \%$ increase from 2007 to 2020 . Furthermore, the data in Figure 3 include a wide range of ages, 15 to 49, though laws and interventions have changed significantly in the decades between those age groups. In most countries listed in Table 2, except for The Gambia and Somalia, the prevalence of FGM among 15- to 19-year-olds is recorded to be lower than the prevalence among the entire range of 15- to 49-year-olds ${ }^{27}$. These changes are most likely due to the activism, research, and legislation of the last few decades ${ }^{28}$.

The inclusion of FGM in the UN Sustainable Development Goals (SDGs) reflects the prevalence of FGM and the ongoing global battle to end it. Target 5.3 of the SDGs attempts to "eliminate all harmful practices, such as child, early and forced marriage, and female genital mutilation" 29 . Established in 2015, the SDGs have until 2030 to do so. The practice has become less common in many countries, but in order to reach the global target of elimination by 2030, progress would need to be 10 times faster ${ }^{30}$. Moreover, progress is not yet universal. It is particularly difficult to address FGM in locations where prevalence is unknown.

\section{Performance for Development and Health}

"Performance for development" is not an established term within the arts, but one that this study will use to encompass the performative art forms beyond theater, including radio, film, puppetry, and public demonstrations. This term draws on "Theater for Development (TfD)" which is defined as "an alternative communication strategy which is people-centered and is deeply rooted in community development by empowering marginalized groups to consciously take up the onus of effecting some change within their immediate environment" ${ }^{\text {"31. Performance for }}$ development aims to provide people with an improved quality of life, in line with the SDGs mentioned above. This chapter will describe the theoretical frameworks that guide impact in each art form.

\subsection{Prevention}

$\mathrm{TfD}$ can encompass the art forms of drama, comedy, spoken-word, music, singing and/or dance, miming, and participatory or improvisation forms. This field is rooted in two concepts: a critical pedagogy and participatory theater ${ }^{32}$. The former was developed in the late 1960s and articulated by Paulo Freire, whose literacy campaigns for adult education in South America led to the development of a pedagogy of liberation. Freire proposes learning centered on the reality of the learner with dialogue between teacher and student. These values led to the formation of the Freirean dialogic model, which engages learners, facilitators, and the community in a critical reflection of its situation in order to create social change ${ }^{32}$. In his evaluation of TfD, Tim Prentki connected Freire's student-centered pedagogy to community-centered theater, or "theater which takes as its starting point an issue or set of issues that are revealed as important by research processes 
that set a premium on listening to the experiences of all sections of that community" ${ }^{32}$. Freire's work generates critical community consciousness and empowers its members to take action.

The second root, participatory theater, comes from the work of Augusto Boal, who built upon the work of Freire to bring theater back to styles more similar to those of medieval European carnival forms, before the ruling class commanded theater $^{32}$. In his book Theatre of the Oppressed, Augusto Boal introduces forms of theater where "the spectator starts acting again," including forum theater, image theater, and invisible theater ${ }^{33}$. Boal describes the central purpose of participatory theater by explaining its function within illiteracy. He relays that theater can serve the oppressed as a language ${ }^{33}$. His design for this communication, named forum theater, involves the spectator assuming the role of the protagonist to change the dramatic action, try out solutions, and discuss plans for change. In this way, the performance is a "rehearsal for the revolution," as Boal famously declared. He adds that he believes that "theater is a weapon, and it is the people who should wield it" $^{\prime 3}$. Boal is clear in his interpretation of theater as a tool by which people can create change.

Boal's model of participatory theater, as shaped by his design for the theater of the oppressed, has impacted the function of existing programs today. Hara TV 3, an interactive theater-based FGM intervention, describes interactive theater as breaking the "fourth wall" in order to "illustrate real-life political and moral debates" 34 . They explain that interactive theater gives the audience an opportunity "to become the main characters on the stage." This type of engagement is crucial because it allows audience members to empathize with the actors, linking their own lives and stories to the one being told. In this way, TfD prevents FGM through its ability to educate and empower survivors and their communities to speak and act out against FGM, proactively reducing the practice before it occurs.

\subsection{Treatment}

In the realm of treatment, the concept of drama therapy is central to the nexus of theater and treatment. The first theoretical account of drama therapy is based in Greek theater, specifically the tragedy ${ }^{35}$. Aristotle portrays tragedy as a catharsis which releases deep feelings ${ }^{61}$. Building on Aristotle's work, in 1857, Jacob Bernays proposed a theory that "catharsis" is a medical metaphor, connecting the purge of the soul through tragedy ${ }^{33}$. In a modern context, author Emma Brodzinski describes drama therapy as a psychological therapy in her book Theatre in Health and Care ${ }^{36}$. The drama therapist combines the art form with psychotherapy practice to enhance well-being by building trusting relationships, developing communication and social interaction skills, exploring feelings to overcome negative mental health effects, and developing creative skills for self-advocacy ${ }^{37}$. It is a creative and clinical procedure. That is, in the case of treating FGM survivors, drama therapy is primarily utilized as a method of mental health care, focused on increasing self-esteem and working through trauma.

Film is recognized as a method of providing a common language for communication in multilingual societies. Much like with theater in non-literate communities, film acts to bridge gaps, though its mass distribution is less accessible in rural villages. In his 1971 UNESCO report on the role of film in development, Peter Hopkinson notes the ability of film to "create a climate for practical innovation, stimulate the thirst for knowledge, and provide instruction, in particular fields, such as agriculture and health." Film, in its capacity to contribute to better health outcomes, can support educational efforts, target stigma through empathetic appeal, and foster awareness for a particular issue ${ }^{66}$. In the Health Evidence Network Synthesis Report 67, film is reported as being effective in reducing ethnic tensions and improving cultural competence, reducing pain and distress (through virtual reality relaxation), and 
improving parental attitudes towards LGBTQidentifying children ${ }^{4}$.

\subsection{Awareness}

Performing arts also have the ability to increase advocacy, reaching new audiences and increasing private donor funding to the cause of FGM. There are a plethora of shows and films depicting the story of FGM. In her play Emotional Creature, Eve Ensler features the monologue of a girl who runs away from her family to avoid undergoing FGM. The monologue depicts the girl praying for her god to spare her. These types of work may be the first point of exposure of many communities to FGM. In 2016, there was a popular play named Cuttin' It that toured in the United Kingdom. This play specifically exposes the prevalence of FGM in developed countries and introduces the audience to that specific experience in a "sensitive exploration"38. While many of these performances are exclusively shown in high-income countries, their influence on public opinion and increased attention is invaluable. Performance has the unique ability and great potential to cover a range of work in the fight against FGM, by using a community-based approach, providing education experiences, inciting activism, and including sensitization work.

\section{Assessing Existing Prevention Programs}

The theories of planned behavior and social networks effectively demonstrate that in order to intervene in a holistic manner that addresses all levels of the socio-ecological model as demonstrated in Figures 1 and 2, interventions must target planned behavior, change subjective norms, and establish community health workers or activists. These theories also connect to the ideals set forth by the developers of TfD, emphasizing the need to incorporate the whole community in a grassroots approach that meets their cultural needs, while pushing towards the abandonment of FGM. Beyond this overarching framework of health promotion, performance interventions should also meet the needs of FGM specifically. Plan International, an independent development and humanitarian organization focused on advancing children's rights and equality for girls, presents seven ways to end FGM. NGOs that counter FGM use these methods to better understand the existing programs working in performing arts and FGM and what they accomplish. Note that the methods often do not exist in isolation of each other, but often cross over.

Out of the programs observed, many fall into two models. The interventions are either performance-oriented or workshop-oriented with performance aspects. In the performance-oriented design, the projects usually focus on a play, radio show, or other performance then incorporate a forum for discussion. The second design often features a central workshop oriented around performance with other components, sometimes concluding in a performance. Both models work as effective methods because of their connection to traditional health promotion frameworks, through their ability to fulfill the seven following methods of ending FGM.

\subsection{Challenging discriminatory reasons for FGM}

The first method is to challenge the discriminatory reasons underpinning the practice of $\mathrm{FGM}^{3}$. These include the need to control female sexuality and gender roles. By targeting these underlying assumptions, traditions can be challenged in a way that understands cultural perspective. Through interactive theater, drama workshops, and puppet shows, organizations fighting FGM target underlying beliefs about girls that lead to FGM. The different art forms depict alternate realities where women are empowered, allowing communities to imagine a future with new gender norms and treatment of women.

Tostan International, a West African-based development organization working directly with rural communities, does not focus specifically on FGM, but their programs report changes in FGM 
practices $^{39}$. Their workshops primarily focus on education in democracy and human rights, which facilitate conversations about women's rights. Participants learn materials that encourages them to challenge preexisting notions and decide how they feel about FGM based on shared values and concepts of human rights. The participants engage with FGM by choice, after being introduced to the broader field of human rights and shape their curriculum through their own actions. Although Tostan did not intend to end FGM, between August 1997 and December 2009 its educational programs, which involved theater as a method of learning about human rights and encouraged public theater as a form of protest, challenged traditional notions on a widescale, fostering numerous collective declarations abandoning FGM.

Organizations successfully reproduce this methodology in other settings: Plan International works with Sahar Education, an international nonprofit providing education to Afghan girls, to produce educational puppet shows to target FGM in Egypt; ARC Theater works in East London to train teachers about FGM, targeting any biases that might exist and training them to account for the underlying reasons of FGM; and Active Voices uses dramas to address the needs of youth specifically ${ }^{40,41,42}$.

\subsection{Change Traditions}

The decision to abandon the practice of FGM must come from the communities themselves, reflect a collective choice, be reinforced publicly, and be grounded on a firm human rights foundation $^{18}$. In doing so, communities can direct their own social transformation, thus changing traditions so that individuals and families do not feel as if they are breaking away from their community by denying FGM. Through community workshops and programs, organizations involve all members of the community, including village leaders, religious leaders, circumcisers, and families. Tostan and Hara TV present two great examples of how these programs manifest and yield effective results.

Tostan's Community Empowerment Program exemplifies work that directly involves communities in the transformation of traditions. The class honed in on human rights, democracy, and governance and incorporated multiple teaching methods. Diane Gillespie from Tostan International believes that theater exercises in particular kept people coming to class, because they engage everyone involved ${ }^{39}$. Exercises include everything from simple "invisible ball" exercises, where participants pass an invisible ball to connect with each other, to writing and performing their own skits.

As a result of these classes, participants came to the understanding that FGM could change. Sessions in human rights and democracy, showed participants that their voices have a place in society and can effect change. Learning about an international human rights framework empowered participants to challenge existing social norms such as $\mathrm{FGM}^{43}$. In a report Gillespie wrote with her sister, the founder of Tostan, Molly Melching, on the transformation of Tostan's approach, they report that the culmination of a workshop in 1997 involved a community effort that collectively abandoned the practice of $\mathrm{FGC}^{43}$. The data collected reports abandonment in 4,121 communities in Senegal, 364 in Guinea, 48 in The Gambia, 34 in Somalia, and 23 in Burkina Faso ${ }^{43}$.

Hara TV is a fast-paced, interactive, comedic project in Egypt that uses theater to educate people about FGM. Like the example in Ijurin, Nigeria, this project also incorporates community participation. While the show is performed by two actors from the project, the director asks the audience questions throughout the performance to ignite discussion. The article "Using comedy to combat a cruel tradition," describes the past performances of the Hara TV troupe. In one performance depicted, the group interacts with an audience of 40 circumcised girls varying from ages 13 to $20^{1}$. The director of the project states that the troupe's goal is to "use our performance to create 
an opportunity to talk about the difficult topic of female genital mutilation, beyond the confines of religion or medicine, in very practical terms." The performance comedically depicts a mother warning her daughter about the effects of not going through FGM, a girl being told what not to do and wear, and more. These scenes are followed by conversations where the audience is able to open up about their experiences, from not being able to play in the streets like boys to having many duties in the home. Actress Sherin Hegazy, who performs in the show, believes $70 \%$ of the message is communicated through the conversation after the show, explaining that in the conversation they are able to disagree, clarify misunderstandings, and answer questions from the audience ${ }^{44}$.

After the event, one 18-years old female expresses, "Now that I've seen the play, I understand the problems circumcisions cause for girls." Another woman in the audience with a 13year-old-daughter explains that while she has been thinking of having her daughter circumcised, after seeing the performance, she will not. Even though those in the audience had all already undergone FGM, the play encouraged them to stop the practice in the future. In this way, the play takes a grassroots approach, reaching communities through individuals within them.

After the director Nada Sabet sold her piece to the United Nations, they decided to fund an additional 160 performances in Egypt in 2014. Approximately 200 performances have taken place in Egypt since its commencement ${ }^{34}$. In a 2016 report "Hara TV: The Journey," written by Noon Creative Enterprises and UNFPA, the organizations report that in villages in upper and lower Egypt, the interactive theater activities achieved efficient communication of anti-FGM and anti-early marriage messages as well as establish the importance of creative methods of learning ${ }^{44}$.

In a 2016 report on their programs, Noon Creative Enterprise explains its methodology behind Hara TV 3:

"As such their engagement is not based on laughing about FGM; it rather laughs at the many wrong facts, myths and misconceptions that communities hold onto to maintain the practice. Making those facts into a public and collective laughing matter, communities become accomplices in the change movement."

Noon Creative enterprise highlights the idea that FGM is most effectively abandoned by a community when they work together rather than individually ${ }^{18}$. Both Hara TV and Tostan work within communities to produce approaches that are non-judgmental and encourage collective action.

\subsection{Educate girls on their bodily autonomy}

Several recent studies have demonstrated that female education writ large is associated with a decline in FGM ${ }^{45,46,47,48}$. Sanaba, a 24-year-old mother from Mali, who was one of the last girls in her family to undergo FGM, asserts, "No child who is well informed and able to stand up for himself or herself wants the practice of genital cutting to continue." As a mother's level of education rises, the likelihood that her daughter undergoes FGM declines ${ }^{47}$. Inversely, when girls undergo FGM they are more likely to drop out of school $^{56}$. Plan International specifically emphasizes the need for curriculum teaching girls to understand their rights and autonomy over their own body ${ }^{3}$. Through creative expression, confidence building, and artistic empowerment exercises, performance can facilitate this learning for girls and women.

A core value of Tostan is dispelling the notion that people are unable to learn. Gillespie explained that some women who attend Tostan's workshops have never spoken outside of the home before and assume that they are "stupid" and cannot learn. Gillespie reports that when theater is incorporated into their practice, "people get so engaged in the plays they forget that they're speaking" 39 . This assertion also relates back to Boal's recognition of theater as a language to serve oppressed communities. In this way, artistic expression is 
uniquely positioned to engage previously untapped learning capabilities.

Beyond theater, Hara organizes music, dance, and visual art workshops for young children ${ }^{44}$. They present a perfect example of the workshop design at the beginning of this chapter. The workshop lasts three days, for a total of nine hours, and culminates in a final hour of a performance. Through singing instruction, participants learn songwriting, composing, and singing to produce songs focused on advocacy. The instructor of this program, Ahmad El Sawy, says "I believe the desired awareness was met along with the participants' acquiring a new skill..." Through dance, Hara indirectly addresses FGM without discussing it. Using dance to establish a relationship with their bodies, participants identify its dimensions and capabilities, gaining ownership and comfort with their physical self. One exercise asks participants to recall painful memories associated with their body parts, connecting girls understanding of FGM to their physical body, and empowering bodily autonomy.

The YouTube video "Ending Female Genital Cutting in Guinea" features a workshop presented by Plan International and AFAF, an NGO educating girls about the dangers of excision ${ }^{49}$. In the workshop, the girls learn about excision, reproduction, and more using song and music. The workshop utilizes a participatory and community approach based on dialogue. At the end of the program the students march, dance, and sing to campaign against FGM. As a result of this program, the village came out against excision. In this example, education translated to a public demonstration which increased awareness of the negative risks and FGM in a way that communicated to the whole village.

\subsection{Speak out about the risks and realities of FGM}

Through non-judgmental and non-coercive public discussion, reflection, and storytelling, communities affected by FGM can come to understand the risks of $\mathrm{FGM}^{18}$. The Girl Generation, the world's largest collective of organizations working together to end FGM in the current generation, recommends positive storytelling as an effective intervention, reporting that "sharing what is happening is essential to building awareness. Research shows that stories are more effective than facts, explanations, or arguments in influencing behavioral change $\mathrm{e}^{50}$. Their effectiveness is attributed to their ability to transport the reader, engage empathy, garner attention, and leave a memory. As mentioned in Section 4, theater and film act as natural forms of storytelling, facilitating awareness as unique platforms for advocates against FGM.

The international non-profit organization Right to Play utilizes radio dramas to empower youth to speak out against FGM ${ }^{51}$. Girls in the program write and perform the radio dramas to share stories that work towards gender equality. In the feature radio drama, the story focuses on a teacher who stands up for a girl, Matinde, bullied for not being circumcised. In the end, the other children accept her decision. The young Matinde is depicted as a champion for girls' rights in her school. There is no impact measurement for this specific program, but Right to Play claims that through their programs, "more girls are finding their voice, claiming their right to education, and learning to defy dangerous traditions such as female circumcision and child marriage" 52 . They also train teachers how to build trusting relationships so "children gain the confidence to talk about threats to their safety... like female genital mutilation."

The Global Media Campaign, created by former journalists at The Guardian, works to end FGM through innovative media methods across seven countries/territories: Kenya, Mali, Nigeria, Sierra Leone, Somalia, the Gambia, and Puntland $^{53}$. Their work is primarily focused on a grassroots approach that empowers activists through summits and workshops to provide them with training and education on the subject and in the use of film and radio resources ${ }^{53}$. In their Virtual Media Academy, created in May 2020 in response to COVID-19, they have created an extensive online library which includes films and 
webinars. This program was successful in attracting 500 new activists and 175 grants for media campaigns. The Global Media Campaign (GMC) reports reaching 870 million people through the work of their activists working both locally and internationally ${ }^{53}$. Examples of grant programs in Mali include a national slam poetry contest, YouTube education campaigns, and radio shows and debates. Their method of using film and radio to create FGM activists is an especially effective way of exposing the negative effects.

The Kapenguria Theater Group is an antiFGM advocacy program in Kenya that combats the practice of FGM and its risks through theater and song on social media 6 . They are using this moment during lockdown to spread their message widely online, as they expect many teenagers are online more now. The group first records their skits and songs on CDs, then they deliver them to girls in villages to view and discuss. They identify lack of exposure as the primary reason for the continued practice of FGM. Like other programs, their interventions are centered around educating communities on the harmful effects of FGM. Mr. Walufa, the leader of the group, accounts that "many people still don't know that we are using digital methods in the anti-FGM drive"6. Furthermore, by involving community members in the arts programming, these programs create advocates against FGM, both youth and otherwise.

\subsection{Spread understanding that religion does not demand FGM}

Misconceptions regarding religion are often targeted in different performing arts campaigns that address existing beliefs. It is such an involved and prevalent component of existing beliefs, that it merits its own category. Furthermore, by including religious members of the community in the attendance or participation of the arts program, they are effective in addressing religious concerns.

Sadia Hussein, a graduate from the GMC, led a 10-day program in Kenya, featuring religious leaders condemning FGM on radio $^{54}$. The program presented three key results:

1. More than one of four listeners changed their minds and no longer thought FGM was necessary;

2. $87 \%$ of respondents said that FGM had been discussed more than usual in the past month;

3. $100 \%$ of respondents could name at least two harmful effects of FGM after the media campaign, when only $67 \%$ could before the intervention.

In addition to impressive measured results, the media campaign also prides itself in having costeffective interventions, described in further detail in Section 7 on financing. The media campaign plans to continue its work with over five new programs in the next six months.

Cuttin' It, the play by Charlene James that advocates for FGM survivors, combats assumptions about religion by featuring two girls of the same religion, one who undergoes FGM and one that does not ${ }^{55}$. This inclusion of religion in both girls' lives makes the statement that religion is not the cause of FGM. Performing arts interventions are not often centered on targeting religious misconceptions but have the ability to sensitively challenge established beliefs through its programming.

\subsection{Address the secrecy that allows cutting to continue}

Performing arts programs do not directly expose the secrecy of FGM, referencing that it occurs behind closed doors and is seldom the subject of public dialogue, but their public nature encourages open and candid discussion about the topic. For some, a language barrier prevents them from learning about the consequences of FGM and from advocating for themselves and their communities. After participating in the Plan International and AFAF workshop, referenced above, one girl praises the publicity of the intervention, saying, "seeing my mothers and grandmothers campaigning against excision makes 
me happy, because something that was once hidden has now come out" ${ }^{49}$. Public demonstrations are effective in drawing attention to an issue and engaging with non-literate cultures.

Diane Gillespie from Tostan International says "'Seeing is believing' is a huge thing in a nonliterate culture. And female genital cutting is unseen." Tostan is specifically praised for their pedagogy, which builds on cultural traditions of the communities' oral tradition in West Africa. The oral tradition includes storytelling, strong memories, and a variety of languages. In the interview conducted with Gillespie, she explained why Tostan's work necessitates the use of theater ${ }^{39}$. When working in illiterate communities, it is important to rely on oral forms of education and communication, which have the added effect of being interactive and engaging. As mentioned in the previous section, theater often made it easier for participants to engage with the topics. While it is difficult to directly address the issue of genital cutting happening behind closed doors, by encouraging public activism and empowering people to speak on the topic, the reluctancy towards conversing about FGM can be addressed.

\subsection{Keep pushing for FGM to be banned}

Lastly, the seventh method is to "keep pushing for FGM to be banned." In its capacity for advocacy, described in methods 4 and 6, performance-based interventions push for policy change in FGM. In the interview conducted for this study with Chiamaka Uzomba, program director at Active Voices - an organization that tackles critical issues of health and development that has used theater as a form of youth activism against FGM - Uzomba spoke about her experience serving on a national technical working group on FGM in Nigeria. She relayed that within her position in Active Voices, she has the ability to affect the policy choices surrounding $\mathrm{FGM}^{42}$. Though Active Voices has only run one program utilizing theater, Chiamaka hopes to explore it further, once she has more funding, to advocate for a total ban on FGM.

The ability of the arts to impact the abandonment of FGM beyond just the local level, as demonstrated in many aforementioned cases, is incredibly evident through the use of a film in Iraqi Kurdistan. In 2013, two filmmakers in Kurdistan spent almost a decade persuading citizens to talk about the effects of FGM, including impacts on marital sex and family dynamics ${ }^{57}$. The activism of the film helped the Iraqi Kurdistan Parliament outlaw FGM in 2011. In the three years after it was outlawed, there was about a $60 \%$ reduction in the number of girls being cut in the autonomous region ${ }^{57}$. Section 7 focuses more on the translation of performing arts work in FGM to policy affecting broader change.

\subsection{Results of Performance-based Interventions}

Table 4 depicts the varying outcomes of the programs for those that gave any form of measurement. As previously mentioned, many of the programs did not include measures of success. Out of six observed programs/organizations, only two organizations recorded statistics of FGM abandonment following their programs. However, all eight reported positive results in reaction to their projects, either a reduction in reported cases of FGM, community commitments to end FGM, or individual audience proclamations of abandonment. 
https://doi.org/10.48091/BNKO5024

Table 4. Results of FGM and Performance Programs, with their respective outcome measurements

\begin{tabular}{|c|c|c|c|}
\hline Program & $\begin{array}{l}\text { Country/ies where they } \\
\text { work }\end{array}$ & Result & Year \\
\hline Active Voices & Nigeria & $\begin{array}{l}\text { Testimonial of community members } \\
\text { asking for Active Voices to replicate } \\
\text { the program, but no recorded data }\end{array}$ & N.D. \\
\hline ARC Theater & United Kingdom & $\begin{array}{l}\text { "Workshop evaluations found that the } \\
\text { approach was highly popular and } \\
\text { effective, with many scoring } 100 \% \text { on } \\
\text { indicators of knowledge" }\end{array}$ & 2013-2016 \\
\hline $\begin{array}{l}\text { Associazione Italiana } \\
\text { Donne Per Lo Sviluppo } \\
\text { (AIDOS) }\end{array}$ & $\begin{array}{l}\text { Italy, Belgium and other } \\
\text { European countries, } \\
\text { Burkina Faso, Egypt, } \\
\text { Guinea, Mali, Mauritania, } \\
\text { Senegal }\end{array}$ & $\begin{array}{l}\text { One of their advocacy videos has been } \\
\text { used by } 5 \text { African anti-FGM } \\
\text { organizations in the last } 2 \text { years }\end{array}$ & 2018-2020 \\
\hline $\begin{array}{l}\text { Global Media Campaign } \\
\text { (GMC) }\end{array}$ & Mali & $\begin{array}{l}\text { Measures programs in an estimated } \\
\text { total reach on people (varies from } \\
600,000 \text { to } 2 \text { million people) }\end{array}$ & 2020 \\
\hline Hara TV III & Egypt & $\begin{array}{l}\text { Reported proclamations to not carry out } \\
\text { FGM by audience members }\end{array}$ & 2014 \\
\hline $\begin{array}{l}\text { Injurin Intervention } \\
\text { (Adeseke, 2019) }\end{array}$ & Nigeria & Reported 0 cases after the intervention & 2018 \\
\hline Plan International/AFAF & Guinea & The village came out against excision & 2009 \\
\hline Tostan International & $\begin{array}{l}\text { Senegal, Guinea, The } \\
\text { Gambia, Somalia, and } \\
\text { Burkina Faso* }\end{array}$ & $\begin{array}{l}\text { Data collected reports abandonment of } \\
\text { FGM in } 4,121 \text { communities }\end{array}$ & 2010 \\
\hline
\end{tabular}

*listed by highest to lowest number of communities that abandoned FGM

Note. (Uzomba, 2020; Fanelli, 2020; Brown and Porter, 2016; Global Media Campaign, 2020; Lehmann, 2014;

Adeseke, 2019; Plan International, 2009; Gillespie and Melching, 2010)

\subsection{Results of Performance-based Interventions}

\subsubsection{Monitoring and Evaluation}

Monitoring and evaluation of performance-based interventions varied greatly among the observed programs. The methods included informal interviews/testimonials, focus groups, questionnaires, or nothing. All interviewees (representatives of Tostan International, AIDOS, and Active Voices) recognized monitoring and measurement as major challenges of implementing a performing arts program as a health intervention. Measurements are not consistent among art forms either. For radio shows, the measurement might take the form of estimated listeners, but surveys are difficult to conduct because the listenership is not directly recorded. If surveys were to be used, the radio show would have to be played for a controlled group, with the surveys conducted after listening. For a theater performance, there is a more controlled audience, allowing for post-show surveys and a post- 
program follow-up later on. The same is true for workshops in which the participants are contained.

Tostan International primarily relies on surveys and testimonials in order to measure attitudes towards FGM. The choice of these measurements is based on the idea that if a community comes to believe that a practice is harmful, then their attitudes will change, resulting in behavioral change. Unfortunately, the results of surveys are not publicly accessible. Gillespie reported example questions that might be on the surveys to measure prevalence: asking, for example, whether respondents think that most of the people in their community support cutting girls, and if they believe people approve of people who cut their daughters. The development of those questions relies on the idea that an individual is more likely to perform an action if they believe it is socially acceptable.

AIDOS, an Italian organization that combats FGM, by empowering women to create videos fighting against FGM, monitors their success by the number of organizations that use their videos and the views on their videos. The videos are posted on YouTube and periodically monitored for views. Their most popular video has 1,600 views. Without more context from other programs, however, this number is difficult to assess comparatively. Additionally, as behavioral change is a long process, it can be challenging to conduct effective data collection over time ${ }^{44}$. The lack of data reported out from the existing programs presents a challenge for program analysis. These challenges can be mitigated by partnering with local organizations to conduct long-term surveying of the community after the intervention has ended.

\subsubsection{Funding}

Another highly cited issue was funding - for example, one interviewee from Hara TV reported that the program closed in 2020 due to a lack of funding ${ }^{58}$. In light of the COVID-19 pandemic and subsequent government spending to combat its adverse impacts, there is less funding going towards anti-FGM programs. Uzomba from Active Voices and Fanelli from AIDOS both reported that their organizations are dependent on grants in order to conduct more programs ${ }^{59}$. The topic of funding, including the implications of this grant-based funding structure, will be explored further in Chapter 7.

\subsubsection{Research}

Throughout the research process, only one peer-reviewed study was found that measured the prevalence of FGM in a society after using performance as an intervention. Given the scarcity of research on the topic, the topic was investigated through other sources, such as interviews, articles, and video reviews. When there is very little to no previous reported knowledge on the effectiveness of an intervention, it is difficult to gain legitimacy for a program proposal. The lack of reporting and research in general also limits the potential for performance interventions to become more prominent in contributing to the abandonment of FGM.

\subsection{Case Study: Addressing the Menace of Rape and Female Genital Mutilation through Theater for Development, Nigeria}

In 2018, Adefolaju Eben Adeseke conducted one of the first case studies to research the effects of TfD as an intervention in FGM. This study stands out compared to the short-term methods of evaluation used by program interventions because of its long-term and wide-ranging evaluation. Adeseke's study, "Addressing the Menace of Rape and Female Genital Mutilation through Theater for Development" deployed TfD in two Nigerian communities in order to educate people on the issues of FGM and violence against women. In Ijurin, Nigeria, those conducting the study first identified and acquainted themselves with the issue, then developed a solution through the creation of a drama $\mathrm{skit}^{23}$. The cast of the play incorporated traditional songs, community actors and singers, and the elderly. 
The research culminated in a performance for the community that highlighted the story of two girls, one who goes through FGM and one who does not and stays in university. The play directly contrasts the two as a warning and motivation to the audience, while simultaneously educating the viewers on the negative effects of FGM. After the show, the audience, consisting of chiefs, men, women, and children, participated in a postperformance discussion that sparked reflection on the practice of FGM. At the end, Adeseke writes that, "Four of the female circumcisers said that now that they have seen the outcome of FGM in the performance, they would definitely stop the practice." This verbal report is the first measure of success. When the study conducted a "follow-up" a month after the performance, the researchers found that there was no record of circumcision in Ijurin since the facilitators had left. Another check-in three months later displayed the same results. Although the study does not include a numerical record of FGM practiced before the theater program was implemented, Adeseke writes that Ijurin was selected as a site because of "the serious negative impact FGM can have on the female children..." and reports that the study's findings "revealed that many children had died in the past in the village due to hemorrhage." From these explicit mentions of FGM in Ijurin, it is clear that FGM was prevalent beforehand and posed a high risk for young girls. Therefore, the post-intervention shift to zero incidence of female circumcision is remarkable.

In this study, Adeseke proposes the ability of performing arts to intervene in FGM, exemplifying many of Plan International's methods of ending FGM. The study challenges the discriminatory reasons of FGM, changes traditions, and speaks out about the risks and realities of FGM through the performance of the play, which combats misinformation and preconceived notions of FGM. Additionally, by drawing community members to the production, including chiefs, the intervention brings the topic of FGM to the forefront of community interest. The abandonment of FGM in the community also mirrors the push to ban FGM worldwide. While the study does not provide sufficient pre-intervention data, it serves as a strong example of how to conduct monitoring and evaluation after a program, thereby helping solve one of the most significant challenges in the field.

\section{Treatment of FGM Patients using Performance Therapy}

"If health is about adaptation, understanding, and acceptance, then the arts may be more potent than anything medicine has to offer ${ }^{\prime 60}$

Thus far, the ability of performance to act as preventative intervention targeting FGM in a health promotion context has been highlighted. Another area of unexplored potential for performance and health is the capability of performance to serve as therapy. The research study, "Use of Drama Therapy in Unlocking the Voices of Female Genital Mutilation Among the Kenyan Maasai” by Zippora Agatha Okoth, is one of the only existing studies on this specific intersection of drama therapy and FGM. Nonetheless, the Health Evidence Network Synthesis Report on the role of the arts in health reports the effectiveness of art therapy in the case of other health issues, the effects of which are transferrable to the area of FGM. After reviewing both of these documents, it is evident that performance therapy is effective due to its ability to create a safe environment for survivors to process their trauma and to ease mental health symptoms.

\subsection{Safe Spaces, Storytelling, and Trauma}

In her $\mathrm{PhD}$ thesis, Okoth argues that drama therapy, through techniques such as story-telling, role playing, song, and dance, can be used as an effective tool to empower the voices of FGM survivors $^{35}$. After data collection, she reports that theater is particularly effective because "it creates a safe and playful environment where the survivors are able to act out their anxieties, fears, 
and mental conflicts due to $\mathrm{FGM}^{35}$. In this way, theater acts as a buffer for survivors to tell their stories. This strategy works to both help survivors process their emotions and to dispel the stigma of the trauma that arises from being subjected to FGM. The results of the study conclude that after the program, the survivors regained self-confidence, self-esteem, and trust.

In general, expressive art therapy is reported to be effective in helping children and adults experiencing the effects of traumatic experiences, including abuse (physical, emotional, sexual), addiction to drugs, and accidents ${ }^{63}$. FGM falls under the categories of physical, emotional, and sexual abuse. Okoth's study took place at a girls' primary school shelter in Kenya for survivors and escapees of FGM. Girls aged 9-15 participated in drama therapy exercises, including physical warm-ups, imagination exercises - in which participants imagine themselves in different settings or doing different activities games, and storytelling ${ }^{35}$. Overall, the study found several techniques to be helpful in bringing about therapeutic healing to FGM survivors. Through dramatic reenactments, including improvisation and role playing, the participants were able to look at the situation from new perspectives and feel united in their emotions as a group. After testing dance as a method of breaking down boundaries created after FGM, researchers discovered that dance and music as drama therapy techniques proved to be valuable as they helped the participants feel comfortable with their bodies, have physical contact with one another, and dance in front of each other ${ }^{35}$. The removal of these inhibitions allowed the participants to feel more open with their personal experiences. Furthermore, storytelling and games encouraged self-exploration and empowerment.

In order to measure the results of the study, the researchers used the Rosenberg Self Esteem Scale to measure change in attitudes towards self, relationships, and the future. The scale uses a fourpoint scale from "strongly agree" to "strongly disagree" to assign a value to statements reflecting study found that surveyed girls' attitudes towards their lives, relationships, and their future all improved after the project ${ }^{35}$.

\subsection{Mental Health Impacts}

The Health Evidence Network Synthesis Report 67 on the role of the arts in health includes successful examples of the ability of drama therapy programs to address psychological impact. The report cites art therapy (art form unspecified) as improving self-confidence, selfesteem, and self-concept with children who had experienced sexual abuse, developmental delay, or emotional disturbance 4 . For example, dance therapy encourages healthy living by incorporating confidence-building and physical exercise - weekly dance therapy over several months improved body consciousness, body image, and confidence in obese youth. When considering mild to severe mental illness, music and dance therapies were able to reduce anxiety, depression, and other symptoms in children and adolescents. An example of the physical impact of drama therapy is observed in stroke patients. Listening to music and dancing was found to help the development of new neural pathways, improve upper and lower-limb motor function, muscle weakness, balance, grip strength, cadence, and more. Furthermore, music therapy reduced blood pressure in diabetes patients ${ }^{4}$.

There are many other instances of the remarkable effects of drama therapy on physical and emotional wellbeing. Unfortunately, the understanding of performance therapy's impact on FGM survivors is limited. More research should be conducted on the potential physical impact drama and other art therapies can have on this population. Despite the lack of research, though, the wide-ranging impact that performance therapy has been proven to have on similar traumatic experiences holds encouraging implications for interventions regarding FGM. 


\section{Further Considerations and Recommendations}

\subsection{Government Involvement}

Despite the preceding emphasis on grassroots interventions that create community and local programs with the ideals of performance for development, it is also essential that subsequent interventions involve all levels of government in order to generate sustainable and institutional change. While grassroots movements foster awareness of and direct engagement with the threats posed by FGM, these interventions should be followed by codification of their values into law. In this way, the relationship between the government and the broad movement against FGM have a significant, cyclical relationship. As the movement gains traction, it puts increasing pressure on the government to enact meaningful change when the government incorporates these reforms, it further empowers and validates the movement. An example of this relationship includes the HIV/AIDS movement in the United States, in which case activists succeeded in influencing the government to address the epidemic. The combination of grassroots interventions and institutional change can be very effective in targeting FGM.

In general, politicians tend to be hesitant to establish policies relating to the intersection of arts and health overall, not because they do not care about the health issues, but because of the lack of legitimacy and recognition. Lara Dose, the director of the National Network for Arts in Health, observed in 2005 that, "Politicians appear to be sufficiently brave to set targets high enough to raise eyebrows and expectations, but too scared to try anything innovative to ensure these are achieved" ${ }^{36}$. Her criticism comes after the Department of Health in England launched a review of arts and health, and politicians were unresponsive. In 2006, the network ran out of funding and it was suspended. The next paragraphs will examine the ways in which the government has supported FGM and performing arts efforts and give recommendations going forward.

\subsubsection{Emergency Preparedness}

In order to address the increasing rates of FGM described in the introduction, it is essential that preparedness and response plans incorporate FGM in their considerations regarding genderbased violence. With the current spate of instances of FGM owing to the COVID-19 pandemic, future emergency responses should anticipate the extra burden and plan ahead to prevent it. They can do so through health promotion activities and community awareness initiatives that incorporate the techniques enumerated in Section 5.

\subsubsection{Law}

Out of the countries with the highest reported rates of FGM, seen in Table 2, 11 of 16 have made FGM illegal in national policy. According to End FGM Network's March 2020 report, "Female Genital Mutilation/Cutting: A Call for a Global Action," of the population of 92 countries where FGM is practiced, about 55\% (approximately 51 countries) specifically outlaw FGM through national law, either through a specific anti-FGM law or through domestic laws ${ }^{17}$.

In this report, the legal status of FGM in countries is split into three categories: countries that have enacted a special national anti-female genital mutilation/cutting (FGM/C) law; countries in which FGM/C is specifically mentioned/covered within other laws; and countries that do not specifically address FGM/C within their laws. The layers of policy are complex and cross over the realms of constitutional, national, and local law. Table 5 reports the law coverage from the countries listed in Table 2 . Note that all countries included have national representative surveys. 
https://doi.org/10.48091/BNKO5024

Table 5. FGM laws in the countries reporting the highest incidences of FGM

\begin{tabular}{|c|c|c|c|c|c|c|}
\hline Country & $\begin{array}{l}\text { Specifically } \\
\text { address FGM } \\
\text { within their } \\
\text { laws* }\end{array}$ & $\begin{array}{l}\text { Constitution } \\
\text { Prohibits } \\
\text { FGM }\end{array}$ & $\begin{array}{l}\text { National } \\
\text { legislation (NL) } \\
\text { criminalizes act of } \\
\text { FGM }\end{array}$ & $\begin{array}{l}\text { NL criminalizes } \\
\text { participation of } \\
\text { medical } \\
\text { professionals in } \\
\text { acts of FGM }\end{array}$ & $\begin{array}{l}\text { Government has } \\
\text { a strategy in } \\
\text { place to end } \\
\text { FGM }\end{array}$ & Source \\
\hline Somalia & $\mathrm{No}^{* *}$ & $\checkmark$ & $\mathrm{x}$ & $\mathrm{X}$ & $\mathrm{X}$ & Somalia, 2018 \\
\hline Guinea & Yes, other laws & $\mathrm{X}$ & $\checkmark$ & $\checkmark$ & $\checkmark$ & Guinea, 2018 \\
\hline Djibouti & Yes, other laws & $\mathrm{X}$ & $\checkmark$ & $\mathrm{x}$ & $\checkmark$ & Djibouti, 2018 \\
\hline Egypt & Yes, other laws & $\mathrm{X}$ & $\checkmark$ & $\begin{array}{l}\mathrm{X} \text {, prohibits act } \\
\text { without penalty }\end{array}$ & $\checkmark$ & Egypt, 2018 \\
\hline Mali & No & $\mathrm{X}$ & $\mathrm{x}$ & $\mathrm{x}$ & $\checkmark$ & Mali, 2018 \\
\hline Eritrea & $\begin{array}{l}\text { Yes, national } \\
\text { law }\end{array}$ & $\mathrm{X}$ & $\checkmark$ & $\checkmark$ & $\checkmark$ & Eritrea, 2018 \\
\hline Sudan & $\begin{array}{l}\text { Yes, other } \\
\text { laws*** }\end{array}$ & $\mathrm{X}$ & $\mathrm{X}$ & $\mathrm{x}$ & $\checkmark$ & Sudan, 2018 \\
\hline Burkina Faso & Yes, other laws & $\mathrm{X}$ & $\checkmark$ & $\checkmark$ & $\checkmark$ & $\begin{array}{l}\text { Burkina Faso, } \\
2018\end{array}$ \\
\hline Gambia & Yes, other laws & $\mathrm{x}$ & $\checkmark$ & $\mathrm{x}$ & $\checkmark$ & Gambia, 2018 \\
\hline Ethiopia & Yes, other laws & $\mathrm{X}$ & $\checkmark$ & $\mathrm{x}$ & $\checkmark$ & Ethiopia, 2018 \\
\hline Mauritania & Yes, other laws & $\mathrm{X}$ & $\begin{array}{l}\checkmark, \text { but only on } \\
\text { those under } 18\end{array}$ & $\checkmark$, not directly & $\checkmark$ & $\begin{array}{l}\text { Mauritania, } \\
2018\end{array}$ \\
\hline $\begin{array}{l}\text { Guinea- } \\
\text { Bissau }\end{array}$ & $\begin{array}{l}\text { Yes, national } \\
\text { law }\end{array}$ & $\mathrm{x}$ & $\checkmark$ & $\mathrm{X}$, not directly & $\checkmark$ & $\begin{array}{l}\text { Guinea-Bissau } \\
, 2018\end{array}$ \\
\hline Senegal & Yes, other laws & $\checkmark$ & $\mathrm{x}$ & $\checkmark$ & $\checkmark$ & Senegal, 2018 \\
\hline Nigeria & $\begin{array}{l}\text { Yes, other } \\
\text { laws*** }\end{array}$ & $\mathrm{x}$ & $\checkmark$ & $\mathrm{x}$ & $\checkmark$ & Nigeria, 2018 \\
\hline Kenya & $\begin{array}{l}\text { Yes, national } \\
\text { law }\end{array}$ & $\mathrm{x}$ & $\checkmark$ & $\checkmark$ & $\checkmark$ & Kenya, 2018 \\
\hline Uganda & $\begin{array}{l}\text { Yes, national } \\
\text { law }\end{array}$ & $\mathrm{x}$ & $\checkmark$ & $\checkmark$ & $\checkmark$ & Uganda, 2018 \\
\hline $\begin{array}{l}\text { Note. } \\
{ }^{* * T h} \\
\text { natio } \\
\text { FGM } \\
* * * \| \\
\text { state. }\end{array}$ & $\begin{array}{l}\text { Female Genital } \\
\text { omali Constitutio } \\
\text { legislation that } \\
\text { offenses have be } \\
\text { le Sudan and Nig } \\
\text { ithin the country }\end{array}$ & $\begin{array}{l}\text { atting, 2020) } \\
\text { expressly sta }\end{array}$ & $\begin{array}{l}\text { s that the "circumcisid } \\
\text { ents this Constitutiona } \\
\text { der general criminal p } \\
\text { c criminal provisions a } \\
\text { 2018). }\end{array}$ & $\begin{array}{l}n \text { of girls is prohib } \\
\text { provision, and the } \\
\text { ovisions (Female } \\
\text { gainst } F G M / C \text {, the }\end{array}$ & $\begin{array}{l}\text { However, there is } \\
\text { e no known instan } \\
\text { al Cutting, 2020). } \\
\text { ovisions do not app }\end{array}$ & $\begin{array}{l}\text { where } \\
\text { in all }\end{array}$ \\
\hline
\end{tabular}

Other countries where FGM is still legal include Norway, Greece, Poland, Hungary, and 15 states in the United States. As mentioned previously, because the numbers in these countries are not regularly reported, it is difficult to assess how many women and girls are affected ${ }^{17}$. This murky legislative environment reinforces the need for governments around the world to establish laws specifically banning the practice of FGM. Nada Sabet, co-founder of Noon Enterprise - which runs the Hara TV Project - explains the importance of policy through her quote:

"My biggest challenge in the struggle against female genital cutting is the passing of legislation that will outlaw it. Then, and only then, will we be able to put an end to FGM. But it will take a lot of lobbying and advocating, at all levels: in government, in parliament, and in villages and communities"1. 
Governments must explicitly ban FGM in order to strengthen and legitimize the implementation of FGM interventions overall, which naturally includes performance-based interventions.

Beyond the establishment of laws, it is essential to consider the effectiveness and enforcement of those laws. Despite every country in Tables 2 and 5 having a strategy in place to end FGM, the prevalence of FGM is still high in the countries listed. The unambiguous gap between the enactment of laws and the practical enforcement of those laws demonstrates the necessity of interventions that target the root causes of FGM's persistence. Uprooting a harmful societal tradition requires sensitivity and care, which is effectively accomplished through performance.

In the interviews with AIDOS and Active Voices, both organizations stated that work was being done in their respective countries, Italy and Nigeria, to allocate funds to FGM abandonment, but not specifically to performance interventions. Italy passed a law in 2007 that enacted guidelines to health and social work professionals working with migrants from countries where FGM is practiced ${ }^{63}$. In the same year, the Italian government drafted strategic plans aimed at programming initiatives and measures. These campaigns comprised of a documentary, theatrical play, radio shows, TV ads, and more, conducted by seven different Italian antiFGM organizations, including AIDOS ${ }^{59}$. The involvement of the Italian government in anti-
FGM policy and budgetary allocation illustrates the multifaceted role that the legal environment can play in the implementation of anti-FGM performance programs.

\subsubsection{Funding}

As mentioned previously, one of the most significant challenges in performance-based program implementation is receiving proper funding for anti-FGM programs in general. In 2019, Ethiopia spent approximately 78.21 million USD on healthcare costs associated with FGM ${ }^{64}$. This cost is projected to grow to 123.4 million USD in 2048 if Ethiopia does not pursue abandonment more vigorously. If they were to pursue full abandonment, they would lower this projection to 48.03 million USD in 2048. Partial abandonment would lower the costs to about 91.37 million. Considering the heavy financial burden FGM causes for governments, it is within their best financial interest to pursue costeffective interventions.

There is very little data reporting the cost effectiveness of performing arts programs due to an overall lack of research in the area. Even so, the projected costs presented by the GMC's radio and television campaigns are provided in Table 6 to demonstrate the cost efficiency of similar programs. 
https://doi.org/10.48091/BNKO5024

Table 6. The cost per person for radio and TV anti-FGM interventions in Mali

\begin{tabular}{|l|r|r|r|}
\hline Intervention & $\begin{array}{l}\text { Estimated Reach (in } \\
\text { number of people) }\end{array}$ & $\begin{array}{l}\text { Total Estimated Cost } \\
\text { (USD) }\end{array}$ & $\begin{array}{l}\text { Cost per person (USD per } \\
\text { one hundred thousand) }\end{array}$ \\
\hline $\begin{array}{l}1 \text { Hour Radio Show with } \\
\text { education specialist }\end{array}$ & 600,000 & $\$ 650$ & $\$ 108.33$ \\
\hline $\begin{array}{l}1 \text { Hour Radio Debate with } \\
\text { medical doctor }\end{array}$ & 600,000 & $\$ 750$ & $\$ 125$ \\
\hline $\begin{array}{l}1 \text { Hour TV Debate on } \\
\text { Mali TV }\end{array}$ & $1,200,000$ & $\$ 750$ & $\$ 62.50$ \\
\hline $\begin{array}{l}20 \text { anti-FGM ads over 2 } \\
\text { weeks on popular tv } \\
\text { show, Emission Baroni }\end{array}$ & $2,000,000$ & $\$ 2,700$ & $\$ 135$ \\
\hline $\begin{array}{l}\text { National Slam Poetry } \\
\text { Contest }\end{array}$ & $2,000,000$ & $\$ 2,300$ & $\$ 109.66$ \\
\hline $\begin{array}{l}\text { Average cost per person } \\
\text { per one hundred thousand }\end{array}$ & & & \\
\hline
\end{tabular}

Since radio shows, TV ads, and televised debates account for four of five of the interventions in Table 6 , and are primarily indirect interventions, it follows that their successful implementation could contribute to a partial abandonment of FGM. It is projected that if Ethiopia does not put more funding and effort into abandoning FGM, then the country would have about 39.24 million cases by $2048^{64}$. If the Ethiopian government pursues partial abandonment, however, they can lower this projection by 9.86 million cases to have 29.38 million cases in 2048. Applying the average cost per one hundred thousand people of a GMC campaign (\$109.66) to the projected number of reduced cases if partial abandonment is adopted (9.86 million), it would cost about $\$ 10,812$ to accomplish this result. In theory, Ethiopia would only need to spend $\$ 10,812$ USD to save 32.03 million USD in health care costs attributed to FGM. Though these calculations are fairly simplistic, even if the interventions were only half as effective as projected then it still would only cost $\$ 10,812$ USD to save about 16 million dollars in healthcare costs. The Ethiopian government has a limited scope to put FGM policies into practice due to constraints in budget allocation and human resources dedicated to targeting FGM, but with cost-effective strategies such as those of the GMC, the government can work with NGOs to lower their prevalence of FGM $^{65}$.

Valentina Fanelli, a program officer working on FGM, gender stereotypes, and gender- based violence at AIDOS, projects that in the future, in light of the COVID-19 pandemic, the already severely limited funding will be diverted to support economies and emergency efforts ${ }^{59}$. Even so, she also projects that as a result of social distancing measures, more funding will go into media (TV, film, radio) work targeting FGM. Fanelli further explained that AIDOS' programs are grant-dependent, as is the case for many other anti-FGM organizations. Since grant-based funding is relatively inconsistent, this situation puts a great deal of these organizations in vulnerable positions.

These organizations would benefit greatly from an increased government budget allocation, which would provide a more consistent stream of funds. Governments are also financially incentivized to invest in performance interventions in the immediate term, to save on health care costs related to FGM later. In order to support existing performance interventions and contribute to their expansion in the future, governments should allocate more funds to the intersection of arts and health. 


\subsection{Recognition through Research}

One of the primary barriers to effective and innovative work at the nexus of performing arts and the treatment and prevention of FGM is the lack of research. There was only one accessible study on the effects of performing arts on the prevention of FGM and only one on the effects of drama therapy. Furthermore, the former paper included little to no data to substantiate the positive change that it reported. In order for the performing arts to become relevant as an intervention in FGM, there must be more field studies conducted with rigorous and standardized methods of measurement and data reporting. Only then will there be an increase in its legitimacy in academia, policy, and beyond.

In general, there is a lack of research and therefore authority surrounding the role of arts in health. To combat this phenomenon, the same recommendation as above applies with a suggestion that the research agenda be elevated to the multilateral realm. Performance must be considered as a tangible and legitimate health intervention by the WHO, UN, and national health institutions. Improved recognition will translate to increased funding for performance-based programs, hopefully leading to an increase in organizations incorporating the arts in their work.

As of December 2020, only about eight organizations report any link to conducting performing arts intervention to target FGM. In general, these organizations lack standardized measurement and evaluation mechanisms for their programs. Thus, individual organizations should prioritize research in conjunction with their programs in order to increase the overall breadth of research in this area. Furthermore, it is recommended that the WHO establish a formal working group to study and evaluate existing arts and health programs, including those that focus on addressing FGM. While Health Evidence Network Synthesis Report 67 was a great start, it was published only by the regional Europe office. This work must be brought to all regions of the world.

\subsection{Program Pedagogy}

More NGOs, governments, and local health organizations should learn from the success and creativity of the pedagogy of TfD and incorporate more elements thereof in their interventions. These organizations can collaborate with practiced applied theater experts to structure their programs and train volunteers. Furthermore, techniques utilized in performing arts therapy and performance for development should be taught to NGOs through large-scale initiatives and workshops. While the health and performing arts fields are - with only a few notable exceptions isolated from one another, they must initiate cooperative dialogue in order to tackle culturally embedded issues such as FGM.

\section{Conclusion}

An in-depth literature review and assessment of performing arts interventions demonstrates the ability of performance-based interventions to potentially improve conditions for those at risk of FGM as well as survivors. Drawing upon the socio-ecological model, performance can positively impact outcomes by creating awareness, challenging existing norms and underlying assumptions, and empowering girls and community members to speak out against FGM. Performing arts interventions stand out in their natural community engagement, wide potential reach, emotional approach, and cost effectiveness.

In order to pursue performance interventions, there must be a commitment from NGOs to further utilize performance, more robust research and analysis, and increased funding for organizations that facilitate programs in this field. In order to commit to eradicating FGM, both local and national governments must set it as a priority. The criminalization of FGM and enactment of anti-FGM laws legitimize the cause, leading to the opportunity for increased research. With more research, the field can grow in strength, and therefore practice. All of the 
interventions require funding, of course, which is easier to allocate and distribute when there is significant proof of the effectiveness of performing arts interventions. From this paper, the hope is that others will be inspired to research not only the intersection of FGM and performing arts but also the ability of performing arts to effect real change.

The ideal performing arts intervention works within social, local, and institutional networks to create an environment that does not allow for the practice of FGM. In order to further the field, it incorporates effective and thorough monitoring and evaluation before, during, and after the central program. The program itself does not attack culture and tradition, but rather, through its art, invites the audience into a dialogue about FGM. With the precious ability to incite empathy, empower, and educate, performance is a humane solution to this significant global health challenge.

\section{References}

1. Lehmann, E. (2014). Female genital mutilation in Egypt: Using comedy to combat a cruel tradition. Retrieved September 13, 2020, from https://en.qantara.de/content/female-genitalmutilation-in-egypt-using-comedy-to-combata-cruel-tradition

2. UNFPA (2020). Female genital mutilation.

Retrieved November 06, 2020, from https://www.unfpa.org/female-genitalmutilation

3. 7 ways to end FGM. (n.d.). Retrieved November 22, 2020, from https://planinternational.org/sexual-health/7-ways-to-endfgm-for-good

4. Fancourt, D., \& Finn, S. (2019, November 14). What is the evidence on the role of the arts in improving health and well-being? A scoping review (2019). Retrieved November 06,2020, from

https://www.euro.who.int/en/publications/abstr acts/what-is-the-evidence-on-the-role-of-thearts-in-improving-health-and-well-being-ascoping-review-2019
5. Bellizzi, S., Nivoli, A., Lorettu, L., \& Ronzoni, A. R. (2020). Human rights during the COVID-19 pandemic: the issue of female genital mutilations. Public health, 185, 53-54. https://doi.org/10.1016/j.puhe.2020.05.037

6. Kakai, O. (2020, July 16). Study shows FGM, early marriages on the rise in West Pokot. Retrieved 2020, from https://nation.africa/kenya/counties/westpokot/fgm-early-marriages-rise-west-pokot1865870

7. Shimizu, Y. (2020). Health promotion. Retrieved November 22, 2020, from https:/www.who.int/health-topics/healthpromotion

8. Behavioral Change Models. (2019). Retrieved December 01, 2020, from https://sphweb.bumc.bu.edu/otlt/mphmodules/sb/behavioralchangetheories/Behavi oralChangeTheories3.html

9. Brady, B., \& Cahalan, P. (2013, January 06). Special report: Female genital mutilation unreported, ignored and. Retrieved December 01, 2020, from

https://www.independent.co.uk/news/uk/cri me/special-report-female-genital-mutilationunreported-ignored-and-unpunished8439824.html

10. Elmusharaf, S., Elhadi, N., \& Almroth, L. (2006). Reliability of self reported form of female genital mutilation and $\mathrm{WHO}$ classification: cross sectional study. BMJ (Clinical research ed.), 333(7559), 124, https://doi.org/10.1136/bmj.38873.649074.5 5)

11. WHO. (2020, February 3). Female genital mutilation. Retrieved November 06, 2020, from https:/www.who.int/news-room/factsheets/detail/female-genital-mutilation

12. UNFPA-UNICEF Joint Programme on Female Genital Mutilation (2018, August 01).Performance Analysis for Phase II. Retrieved November 06, 2020, from https://www.unfpa.org/publications/performa nce-analysis-phase-ii 
13. Baillot, H., Murray, N., Connelly, E. et al. Addressing female genital mutilation in Europe: a scoping review of approaches to participation, prevention, protection, and provision of services. Int J Equity Health 17, 21 (2018). https://doi.org/10.1186/s12939-0170713-9

14. 28 Too Many. (n.d.). Retrieved November 06, 2020, from https://www.28toomany.org/continent/europe/

15. Ford, L. (2020, March 17). True numbers of FGM victims could be far higher as countries fail to record cases. Retrieved November 06, 2020, from https://www.theguardian.com/globaldevelopment/2020/mar/17/true-numbers-offgm-victims-could-be-far-higher-as-countriesfail-to-record-cases

16. Yoder PS, Khan S (2007). Numbers of Women Circumcised in Africa: The production of a Total. Calverton, Macro International Inc.

17. Female Genital Cutting: A Call for a Global Response. (2020, March). End FGM European Network.

18. UNICEF. (2005). Changing a Harmful Social Convention: Female Genital Mutilation/Cutting [PDF]. United Nations Children's Fund.

19. WHO. (2020, February 6). Female Genital Mutilation Hurts Women and Economies. Retrieved November 14, 2020, from https://www.who.int/news/item/06-02-2020female-genital-mutilation-hurts-women-andeconomies

20. Hayford, S. R., \& Trinitapoli, J. (2011).

Religious differences in female genital cutting: a case study from Burkina Faso. Journal for the scientific study of religion, 50(2), 252-271.

https://doi.org/10.1111/j.14685906.2011.01566.x

21. 28 Too Many. (n.d.). Retrieved November 29, 2020, from

https://www.28toomany.org/thematic/religionand-fgm/
22. Norwegian Church Aid. (2019). Engaging Faith Actors on Gender-Based Violence (GBV) [PDF]. Oslo: Norwegian Church Aid.

23. Adeseke, A. E. (2019). Addressing the Menace of Rape and Female Genital Mutilation through theater for Development. Retrieved September 10, 2020, from http://psjd.icm.edu.pl/psjd/element/bwmeta1 .element.psjd-17806422-3c49-4265-847eedF8f557867f

24. Schmöker, A. (2015). Female genital mutilation - why does it still exist in Africa? ScienceOpenResearch. doi:10.14293/s21991006.1.sor-med.acoxmi.v1

25. UNICEF. (2020, June 11). Data Warehouse. Retrieved November 14, 2020, from https://data.unicef.org/resources/data_explore r/unicef_f/?ag=UNICEF

26. Foster, V., Yonzan, N., Shrestha, J., \& Song, S. (2020, November 11). World Bank Open Data. Retrieved November 14, 2020, from https://data.worldbank.org

27. Goldberg, H., Stupp, P., Okoroh, E., Besera, G., Goodman, D., \& Danel, I. (2016). Female Genital Mutilation/Cutting in the United States: Updated Estimates of Women and Girls at Risk, 2012. Public health reports (Washington, D.C. : 1974), 131(2), 340-347. https://doi.org/10.1177/00333549161310021 8

28. UN Women. (2020, February 4). Looking back and pushing forward: The global fight to end FGM. Retrieved December 01, 2020, from

https://www.unwomen.org/en/news/stories/2 020/1/feature-global-fight-to-end-fgm

29. United Nations Statistics Division (2020). SDG Indicators - SDG Indicators. Retrieved November 06, 2020, from https://unstats.un.org/sdgs/metadata/?Text= \&Goal=5\&Target $=5.3$

30. United Nations Children's Fund, Female Genital Mutilation: A New Generation Calls for Endingan Old Practice, UNICEF, New York, 2020. 
31. Gana, Emmanuel T. Communication and its Increasing Relevance for theater for Development Practice. In Kasewo Samuel et.al. theater Unbound: Reflections on theater for Development and Social Change. SONTA, 2013 111-122.

32. Prentki, T. (1998). Must the Show Go on? The Case for theater For Development (Le spectacle doit-il continuer? Les arguments en faveur du theater pour le développement / O show deve continuar? A questão do Teatro para o Desenvolvimento / ¿Debe continuar el espectáculo? el caso del Teatro para el Desarrollo). Development in Practice, 8(4), 419429. Retrieved November 14, 2020, from http://www.jstor.org/stable/4028911

33. Boal, A. (1993). theater of the oppressed. ProQuest Ebook Central https://ebookcentral.proquest.com

34. Noon Creative Enterprise. (n.d.). Retrieved November 14, 2020, from http://www.noonenterprise.org/en/plays/haratv-3/

35. Okoth, Z. A. (2014, August). USE OF DRAMA THERAPY IN UNLOCKING THE VOICES OF SURVIVORS ... Retrieved October 10, 2020, from http://irlibrary.ku.ac.ke/bitstream/handle/123456789/1 1943/Use\%20of\%20drama\%20therapy\%20in\%2 0unlocking\%20the\%20voices\%20of\%20survivor s\%20of\%20female\%20genital\%20mutilation $\% 2$ 0among\%20the\%20Kenyan\%20Maasai.pdf;seq uence $=1$

36. Brodzinski, E. (2010). theater in health and care. New York, NY: Palgrave Macmillan.

37. Jones, P. (2007). Drama as Therapy: Theory Practice and Research, 2nd Ed.) Sussex: Routledge.

38. Taylor, P. (2016, May 31). A hard-hitting play about the trauma of female genital mutilation. Retrieved December 01, 2020, from https://www.independent.co.uk/artsentertainment/theatre-dance/reviews/cuttin-itYoung-vic-london-review-sensitive- exploration-how-fgm-affects-young-girlsa7058211.html

39. Gillespie, D. (2020, October 13).

Educational Interview with Diane Gillespie from Tostan International [Online interview].

40. Plan International (Producer). (2011, January 18). Female Genital Mutilation in Egypt [Video file]. Retrieved from https://youtu.be/vt_WvI7i_OY

41. Brown, E, Porter, C (2016) 'The Tackling FGM Initiative: Evaluation of the Second Phase (2013-2016)', Options Consultancy Services Limited, London

42. Uzomba, C. (2020, December 1).

Educational Interview with Chiamaka Uzomba from Active Voices [Online interview].

43. Gillespie, D., \& Melching, M. (2010). The Transformative Power of Democracy and Human Rights in Nonformal Education: The Case of Tostan. Adult Education Quarterly, 60(5), 477-498. https://doi.org/10.1177/0741713610363017

44. Hara TV: The Journey [PDF]. (2016). Noon Creative Enterprise. http://www.noonenterprise.org/En/wpcontent/uploads/2017/02/HaraTV-Eng-web2.pdf

45. Shell-Duncan, B. (2008). From health to human rights: Female genital cutting and the politics of intervention. American Anthropologist, 110(2): 225-236.

46. Rawat, R. (2017). The association between economic development, education and FGM in six selected African countries. African Journal of Midwifery and Women's Health, 11(3), 137-146.

doi:10.12968/ajmw.2017.11.3.137

47. ICRW (n.d.). Leveraging Education to End Female Genital Mutilation/Cutting Worldwide [PDF]. International Center for Research on Women.

48. Waigwa, S., Doos, L., Bradbury-Jones, C., \& Taylor, J. (2018). Effectiveness of health 
education as an intervention designed to prevent female genital mutilation/cutting (FGM/C): a systematic review. Reproductive bealth, 15(1), 62. https://doi.org/10.1186/s12978-018-0503-x

49. Plan International (Producer). (2009, May 12). Ending Female Genital Cutting in Guinea [Video file]. Retrieved from https://youtu.be/frE4ghFYeoQ

50. How to use positive stories to end FGM [PDF]. (n.d.). The Girl Generation.

51. Last, J. (Writer), \& Right to Play (Producer). (2020, September 3). Girls in Tanzania Push Back Against Female Genital Mutilation Using Drama [Video file]. Retrieved from https://youtu.be/Nb_7F54IaPo

52. Our Five Pillars. (n.d.). Retrieved November 14, 2020, from https://www.righttoplayusa.org/en/our-fivepillars/

53. We are the Global Media Campaign to End FGM. (2020, May 27). Retrieved November 18, 2020, from https://globalmediacampaign.org/about-us/

54. Impact. (2020, November 02). Retrieved November 18, 2020, from https://globalmediacampaign.org/impact/

55. Healey, V. (2016, June 12). Violence and Female Genital Mutilation Onstage in Charlene James' Cuttin' It. Retrieved December 01, 2020, from

https://howlround.com/violence-and-femalegenital-mutilation-onstage-charlene-jamescuttin-it

56. Ondiek, C. A. (2010). The persistence of female genital mutilation (FGM) and its impact on women's access to education and empowerment: $A$ Study of Kuria District, Nyanza Province, Kenya (Doctoral dissertation, University of South Africa).

57. O'Kane, M., Farrelly, P., Rees, A., \& Baqué, I. (2013, October 24). FGM: The film that changed the law in Kurdistan - video. Retrieved December 04, 2020, from https://www.theguardian.com/society/video/20 13/oct/24/fgm-film-changed-the-lawkurdistan-video

58. Sabet, N. (2020, December 1). Email Interview with Nada Sabet from Noon Creative Enterprise [E-mail interview].

59. Fanelli, V. (2020, November 17). Educational Interview with Valentina Fanelli from AIDOS [Online interview].

60. Art's potent healing qualities offer prescription for a better world. (2003, January 30). Retrieved December 01, 2020, from https://www.smh.com.au/entertainment/artand-design/arts-potent-healing-qualitiesoffer-prescription-for-a-better-world20030130-gdg6qe.html

61. Aristotle. (1954). Rhetoric and the poetics of Aristotle. Trans. Friedrich, S. New York:Random House.

62. Wilson, J. (1997). Dramatic Approaches to Brief Therapy Edited by Alida Gersie. London: Jessica Kingsley. 1995. 273 pp. $£ 16.95$ ISBN 1-85302271-3. British Journal of Psychiatry, 171(6), 592-592. doi:10.1192/S0007125000148949

63. Misiti, Maura. (2016). Eradicating FGM and other harmful practices in Italy.

64. WHO FGM Cost Calculator. (2020). Retrieved December 01, 2020, from https://srhr.org/fgmcost/cost-calculator/

65. Andarge, M. Y. (2014). The Difficulties of Ending Female Genital Mutilation (FGM): Case of Afar Pastoralist Communities in Ethiopia (Unpublished master's thesis). International Institute of Social Studies.

66. Hopkinson, P. (1971). The role of film in development. Paris: Unesco, International Institute for Educational Planning.

67. Ensler, E. (2013). Emotional creature: The secret life of girls around the world. New York, NY: Dramatists Play Service. 


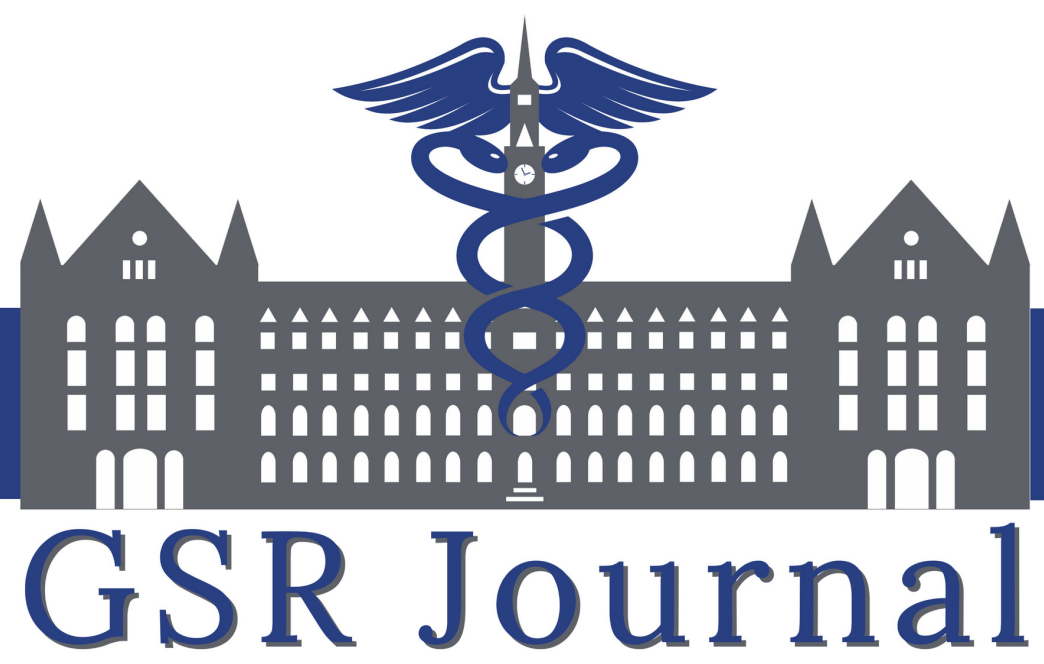

Georgetown Scientific Research Journal 